FILOZOFIA

Roč. 76, 2021, с̌. 4

DOI: https://doi.org/10.31577/filozofia.2021.76.4.3

\title{
JANKÉLÉVITCH A RICGER O POVINNOSTI PAMÄTI
}

DAGMAR SMREKOVÁ, Filozofický ústav Slovenskej akadémie vied, Bratislava, SR

SMREKOVÁ, D.: Jankélévitch and Ricœur on the Duty of Memory

FILOZOFIA, 76, 2021, No 4, pp. $267-280$

This article deals with a specific dimension of collective memory - the duty of memory. It focuses on two philosophical approaches concerning the question of the duty of memory, as represented, on the one hand, by occasional texts of V. Jankélévitch published in the works Imprescriptible (1986), or in L'esprit de résistance (2015), and, on the other hand, the monumental work of P. Ricœur Mémoire, histoire, oubli (2000). In the current discourse on memory and the duty of memory, the work of Ricœur is considered to be a point of reference, while Jankélévitch's views on this question have remained on the fringes of interest - which is, according to the author, unjustified. The article analyses the main philosophical arguments in favour of the idea of the duty of memory, and also justified doubts and reservations. The aim of the article is to show that both of the examined approaches - despite being different from each other - the duty of memory retains its relevance and meaning, regardless of the criticism that considers this concept a possible tool of memory abuse. The author finds a strong argument for categorically rejecting the tendency to forget the Holocaust and defends the duty of memory in Jankélévitch's philosophical analysis of the nature of Holocaust (as a "counter-natural", "metaphysical" crime, based on the denial of the principle of ontological equality of all people). According to the author, the question of the duty of memory is a question of the struggle to protect fundamental human rights and values of European civilization.

Keywords: Duty of memory - Prohibition of forgetting - Misuse of memory - Fair memory - Holocaust - V. Jankélévitch - P. Ricœur

„Zabudnutie nie je l'udské, l'udská je pamät', bdelost' a vernost'. “

Vladimir Jankélévitch

\section{Úvod}

Výraz povinnost' pamäti zahŕňa dva pojmy: pamät' a povinnost'. Pamät' vo význame, aký tu máme na mysli, ${ }^{1}$ sa chápe ako schopnost' selektovania, triedenia, uchovávania

\footnotetext{
${ }^{1}$ Pokial' ide o chápanie pamäti v rámci výrazu povinnost' pamäti, nemáme tu na mysli jej špecifické vymedzenie v neurológii alebo psychológii; ide o pamät' v širšom zmysle, ako k nej pristupujú skúmania pamäti na minulé udalosti, ktoré sa týkajú skupín, respektíve národa, teda v zmysle schopnosti uchovat' a pripomínat' si prežité a naučené, vlastnej skupine, kolektívu.
} 
živých stôp minulosti, obnovenia spomienok na minulé udalosti. Povinnost' v tejto súvislosti stelesňuje záväzok skupín, respektíve národa pamätat' si, a teda nezabudnút' na určité, zvlášt' bolestné a tragické udalosti svojej minulosti. „Na rozdiel od spontánneho fungovania pamäti alebo jej deklaratívnej a naratívnej funkcie sa povinnost' pamäti riadi morálnym imperatívom, ba aj politickým príkazom“(Michel 2018, 3). Tento výraz v jeho súčasnom použití sa primárne vzt’ahuje na špecifický kontext - na pamät' na holokaust. Nejde pritom len o osobné spomienky. Pamät' na holokaust (zločin kvalifikovaný norimberským tribunálom ako zločin proti l’udskosti) je kolektívny fenomén. Prvým impulzom pre vynájdenie súčasného výrazu povinnost' pamäti boli povojnové združenia a organizácie deportovaných, ktorí mali priame poznanie a bezprostrednú skúsenost's nacistickými koncentračnými a vyhladzovacími tábormi, a ich záväzok uctit' si pamiatku obetí a vydat' o prežitom utrpení a ponížení autentické svedectvo.

Viacerí autori (napr. historici H. Rousso, H. Wievorka) pripisujú vynájdenie termínu povinnost' pamäti talianskemu esejistovi Primo Levimu, ktorý prežil Auschwitz, a jeho knižke, vydanej vo francúzštine posmrtne pod titulom Povinnost' pamäti (Le devoir de mémoire 1995) na základe rozhovoru z roku 1983. Levi v nej výslovne nespomína povinnost' pamäti, ale povinnost' tých, čo prežili, podat' svedectvo o skúsenostiach z táborov smrti. Táto publikácia, ako aj znovuobjavenie Leviho diela síce spopularizovali termín povinnost' pamäti $\mathrm{v}$ súvislosti s pät'desiatym výročím oslobodenia táborov, no ako pripomína $\mathrm{O}$. Lalieu, tento titul nepochádza od P. Leviho. Vybral si ho vydavatel', pretože bol módny a pretože presmeroval obsah rozhovoru na otázky o potomkoch Auschwitzu (Lalieu 2001, 83 - 84). K formulácii pojmu povinnost' pamäti dochádza v devät'desiatych rokoch a od tohto obdobia sa tento pojem týka aj d’alších zločinov genocídy.

Na prvý pohl'ad by uplatnenie povinnosti vo vzt'ahu k pamäti nemuselo vyvolávat' pochybnosti. Jej prijatie - ako poznamenal E. Kattan - sa nám dokonca javí ako oprávnené, pokial' ide o zločiny proti l'udskosti alebo o krivdy a bezprávie, masovo páchané na určitých skupinách či národoch. Povinnost' pamätat' na nacistické zločiny by teda mala byt' namieste ako memento pred návratom fašizmu. A rovnako kategoricky by sme si mali uchovat' pamät' na obete gulagov ako výraz odporu proti všetkým formám totality. Podl'a Kattana sa zdá, že povinnost' pamäti v týchto kontextoch preberá nespochybnitel'né dôkazy (Kattan 2002, 8 - 9). A predsa sú názory teoretikov na túto otázku protichodné. Čast' autorov proti cielenému či spontánnemu zabudnutiu zdôrazňuje dôležitost' povinnosti pamäti, najmä pokial' ide o masovo páchané zločiny, ktorých obet'ami sa stali nielen jednotlivci, ale aj celé skupiny a národy. Na druhej strane názorového spektra stoja autori, ktorí varujú pred nadužívaním povinnosti pamäti, najmä ked' je táto povinnost' imperatívne vynucovaná a kontrolovaná štátom. V tejto súvislosti vznikajú 
viaceré otázky: Existuje univerzálna povinnost' pamäti, jej verejného „uznania“, jej legitimizovania, alebo sa táto povinnost' vzt'ahuje len na skupiny, ktoré boli priamo dotknuté zločinmi? Na aký typ udalostí sa taká povinnost' vzt'ahuje a v záujme koho, respektíve v mene akých hodnôt sa pamät' má podriadit' povinnosti? Akú povahu má táto povinnost' a kto je jej adresátom?

So zretel'om na tieto otázky budeme v článku najprv analyzovat' hlavné filozofické argumenty v prospech povinnosti pamäti, ako ich formuloval V. Jankélévitch vo svojich príležitostných povojnových textoch, vydaných posmrtne knižne pod titulmi Nepremlčatel'né (Jankélévitch 1986) a Duch odporu (Jankélévitch 2015). Tento krok má z nášho hladiska dobrý dôvod: Uvedené texty totiž zostali v rámci skúmaní venovaných zrodu aktuálneho konceptu povinnosti pamäti na okraji záujmu teoretikov pamäti - no podl'a našej mienky neprávom. ${ }^{2}$ Pravda, myšlienka založenia pamäti na povinnosti vyvolala aj určité pochybnosti. $\mathrm{V}$ tejto súvislosti sa zameriame na eticko-politickú kritiku povinnosti pamäti, ktorej reprezentatívnym príkladom je Jankélévitchov súčasník P. Ricœur a jeho dielo Pamät', dejiny, zabudnutie. ${ }^{3}$ Sústredíme sa na Ricœurove protiargumenty, upozorňujúce na úskalia prístupu, založeného na imperatívnych nárokoch na pamät', ako aj na jeho úsilie rozvinút' v kontraste s povinnostou pamäti pojem práca pamäti (fr. le travail de mémoire) ako súčast' spravodlivej pamäti (fr. la juste mémoire). Ciel’om článku je ukázat', že oba skúmané prístupy - akokol'vek navzájom rozdielne - poskytujú argumenty na potvrdenie relevancie a zmyslu povinnosti pamäti, napriek kritike, ktorá v tomto koncepte identifikuje možný nástroj zneužitia pamäti.

\footnotetext{
${ }^{2}$ Ojedinelú pozornost' Jankélévitchovmu stanovisku, ktoré sa týka pamäti ako morálnej povinnosti v česko-slovenskom prostredí, venuje N. Maslowski vo svojej štúdii Politika paměti jako nástroj manipulace a morálky. Maslowski cituje známy Jankélévitchov výrok z textu Nepremlčatel'né: „Odpustenie zomrelo v táboroch smrti“, pričom zároveň pripomína, že „,neodpustit““ v kontexte Jankélévitchovho uvažovania znamená tiež ,pamätat' si“, a teda nezabudnút'; ide fakticky o jedinú možnost', ako morálne čelit' hrôze zločinov proti l'udskosti (Maslowski 2014, 75 - 76).

${ }^{3}$ Ricœurovo dielo Pamät', dejiny, zabudnutie (Ricœur 2000) vyvolalo hned' po svojom vydaní ohlas, ktorý bol podl'a vyjadrenia F. Dossa neporovnatel'ný s jeho predchádzajúcimi dielami a d’aleko presiahol úzky okruh filozofov a historikov (Detailnejšie Dosse 2008, 659-660). Ricœur výrazne zasiahol do diskusií nielen o povinnosti pamäti, ale aj o vzt'ahu medzi pamät'ou a históriou a o otázke viny (kriminálnej, politickej aj morálnej) a odpustenia, ktoré chápal ako „spoločný horizont pamäti, histórie a zabudnutia“ (Ricœur 2000, 593). Ricœurov vzt'ah k histórii skúma J. Sivák v článku Ricœur ako metodológ dejín, kde ukazuje, že aj ked’ dnešná historiografia sa rozprávaniu a „udalostným dejinám“ vzd’al'uje, pre Ricœura história je nad’alej rozprávaním a jeho zásluhou je to, že „ukázal rozprávačskú identitu nielen týchto javov, ale aj aktérov dejín, jednotlivých i kolektívnych“ (Sivák 2013, 764).
} 
Zákaz zabudnutia ako morálny záväzok pre pamät': stanovisko V. Jankélévitcha Francúzske vydanie rozhovoru P. Leviho o povinnosti svedectva viacerí autori identifikujú ako prvotný zdroj rozšírenia termínu povinnost' pamäti vo francúzskom prostredí. Podl'a našej mienky porovnatel'ný paradigmatický význam majú povojnové príležitostné texty morálneho filozofa V. Jankélévitcha Čestne a dôstojne z roku 1948 a Odpustit? (vydané neskôr knižne s názvom Nepremlčatelné), ako aj pôvodne nevydané texty z roku 1943 - 1983 (publikované pod titulom Duch odporu v roku 2015). V tomto kontexte by sme chceli vyzdvihnút' dva momenty, ktoré sa zvyknú prehliadnut'.

$\mathrm{V}$ prvom rade treba upriamit' pozornost' na anotáciu vydavatela knižnej podoby publikácie Nepremlčatel’né. Na zadnej strane obálky výslovne uvádza: „Túto reedíciu by bolo l'ahké ospravedlnit' tým, že sme si na aktuálnom stave všimli viaceré znaky, ktoré naznačujú úpadok pamäti a dejín, no to by znamenalo zradit' predčasný a metafyzický charakter toho, čo tu píše Jankélévitch. Filozof príležitosti nikdy nepovažoval za správne čakat' na ,príležitost' vyjadrit' svoj hnev a l'útost'. Vždy si našiel okamžik, aby pripomenul, že pamät' na hrôzu predstavuje morálnu povinnost"“ (Jankélévitch 1986, zadná obálka). A po druhé, treba si uvedomit', že paralelne s Jankélévitchovými článkami, vyznačujúcimi sa kritickým a hnevlivým tónom namiereným voči polemike o premlčatel'nosti nacistických zločinov genocídy a na tendenciu zabudnút' na udalost' masového vyhladzovania, vyšla jeho filozofická esej Odpustenie (Le pardon 1967). Táto esej upútala odhalením paradoxnej, až škandalóznej povahy pravého odpustenia. Poukázala na jeho všemocnost' a nemožnost' zároveň, na to, že odpustenie v sebe zahŕňa prekážku, ktorú treba prekonat', ako aj na to, že pravému odpusteniu konkurujú rozličné formy imitácií odpustenia, ktoré toto gesto zbavujú čistoty a úprimnosti. ${ }^{4}$ $\mathrm{V}$ tomto kontexte treba zdôraznit', že Jankélévitch nikdy nezamieňal odpustenie so zabudnutím, s vymazaním pamäti na zločiny. Napriek vlastnému presvedčeniu o všemocnosti pravého odpustenia absolútne nepripúšt’al, že by právne nepremlčatel'né mohlo byt' niekedy v budúcnosti odpustené a zabudnuté, povedzme pod vplyvom „hojivého“ účinku času. Neodpustitel'né morálne zaväzuje pamät' a vylučuje zabudnutie. A Jankélévitchove príležitostné povojnové texty sú dôslednou obranou tohto jeho principiálneho postoja.

V článku nazvanom Čestne a dôstojne, ktorý vyšiel v revue Les temps modernes v roku 1948, sa záväzok spojený s pamätou ešte nespomína priamo. No jasne v ňom badat' autorovo morálne rozhorčenie nad laxnost'ou, $\mathrm{s}$ akou sa čast' spoločnosti preniesla ponad hrôzy prežitých vojnových udalostí. V konfrontácii so zažitou realitou je

\footnotetext{
${ }^{4}$ P. Sucharek na vysvetlenie paradoxnej tváre odpustenia výstižne poznamenal: „Pred problém odpustenia v modernom zmysle nás skrátka postavila nemecká vina, pričom filozofická reflexia vo väčšine prípadov (Adorno, Levinas, Jankélévitch a Arendtová) tento problém nastolila súčasne s jeho zamietnutím“ (Sucharek 2017, 421).
} 
tu čitatel'ný údiv aj hnev, ktoré sa vzt'ahujú na disproporciu medzi obludnost'ou týchto udalostí, zoči-voči ktorým slovo vykúpenie stratilo zmysel, a bezvýznamnost’ou zmien, ktoré tieto kataklizmy znamenali pre francúzske mravy, pre sociálnu štruktúru, ekonomické vzt'ahy tried a pre vzájomné vzt'ahy občanov. „Je takmer bezpríkladné, že tol'ké utrpenie tak málo zmenilo osud l'udí, že také ohromné otrasy zrodili také priemerné povojnové obdobie“ (Jankélévitch 1986, 99). Ďalej dodáva: „To, čo žijeme, nezodpovedá tomu, čo sme utrpeli“ (tamže). V náznakoch tu badat’ Jankélévitchovu výčitku, že l'udia akoby náhle stratili pamät' na hrôzy bezprostrednej minulosti, alebo ju zámerne odložili ad acta s tým, že život ide d'alej. Pravda, v čase, ked' vyšiel zmienený článok, jeho autor ešte nemohol tušit', že francúzsky parlament v roku 1965, teda s odstupom prakticky dvoch desat'ročí od skončenia druhej svetovej vojny, prijme zákon o nepremlčatel'nosti nacistických zločinov proti l’udskosti. Aj po tomto zákonodarnom akte však považoval za dôležité verejne odporovat' vytrvalým obhajcom premlčania, ktorí neváhali hl'adat' pre páchatel'ov týchto zločinov pol'ahčujúce okolnosti.

Jankélévitchov postoj by sme však nemali vnímat' len v rovine psychologického výrazu rozhorčenia a hnevu, hoci ide o legitímny prejav obete nacistického prenasledovania a deportácie. Ide totiž zároveň o apel na kolektívnu pamät' na nadosobnej úrovni, opierajúci sa o filozofický rozbor povahy zločinu holokaustu. $\mathrm{V}$ tomto kontexte si osobitú pozornost' zaslúži tá čast' diela Duch odporu, do ktorej editorka F. Schwab začlenila sériu Jankélévitchových článkov, explicitne alebo implicitne venovaných zákazu zabudnutia a povinnosti pamäti. Jankélévitchova pozícia v článkoch zahrnutých do časti Zabudnutie zakázané (ktoré sa v modifikovanej verzii objavili v knižke Nepremlčatel’né) je charakteristická tým, že právny princíp nepremlčatel'nosti zločinov nacistickej genocídy kompletizuje poskytnutím filozofických a morálnych argumentov, aby tak presvedčivo zdôvodnil túto výnimku z právnych princípov. Význam povinnosti pamäti pretavuje do kategorického imperatívu, ktorý prikazuje nezabudnút' na holokaust. Jankélévitch chce byt' zárukou, že sa nezabudne na tých, ktorí ostali $\mathrm{v}$ táboroch smrti. Lenže ako urobit' zadost' povinnosti podat' o ich tragickom osude svedectvo, ako zaistit' prenos pamäti z generácie na generáciu, ako potomkom vysvetlit', komu sme dlžníkmi a čoho sme dedičmi, ked’ to, čo sa dialo vo vyhladzovacích táboroch, bolo z rodu nepredstavitel'ného, nevyslovitel'ného? Teda niečoho, čo je od tohto okamihu tajomstvom nie jednej nešt'astnej generácie, ale moderného človeka ako takého? V článku Zabudnutie zakázané z roku 1965 autor priznáva, že „l'udia jeho generácie sa niekedy cítia byt' nositel'mi t’aživého a nepriznaného tajomstva, ktoré ich oddel'uje od ich detí. Ako im povedia pravdu?“ (Jankélévitch 2015, 185)

Pamät' na holokaust bola dlho predmetom obojstranného mlčania, ked’že tí, ktorí prežili deportácie a tábory smrti, boli spočiatku konfrontovaní s nevôlou zo strany 
iných vypočut' ich osobné svedectvá, ktorú sprevádzalo nepochopenie, ale aj s vlastnou nespôsobilost'ou vypovedat' o niečom nevyslovitel'nom, nepredstavitel'nom. Udalost' holokaustu znamenala prekročenie hraníc, ktoré sa doposial' pokladali za nedotknutel'né. Univerzálne právo na existenciu odrazu prestalo byt' uznané za základné a životne dôležité právo, ktoré, ako zdôraznnuje Jankélévitch, „musí každý človek u každého druhého rešpektovat', a to bez akéhokol'vek vyjednávania, bez akéhokol'vek nároku na vd’ačnost'“ (Jankélévitch 1986, 22 - 23). Bolo treba prekonat' neprekonatel'nú bariéru, aby sa zadost'učinilo povinnosti zaujat' rolu morálneho svedka s ciel'om uchovat' pamiatku na holokaust ako memento pre d’alšie generácie. Lenže okrem otázky Ako to urobit?? vznikla aj d'alšia: Kto by to mal urobit', komu by táto povinnost' mala pripadnút? Je povinnost' pamätat' na udalost' holokaustu univerzálnou morálnou povinnostou, ktorá sa rovnako týka všetkých - alebo by ju mali na seba prevziat' tí, ktorí náhodou prežili? Lebo o existencii tejto špecifickej povinnosti, ktorá sa týka pamäti, z Jankélévitchovho hl'adiska niet pochýb - už len preto nie, že „to, čo sa stalo, je v histórii niečím ojedinelým a pravdepodobne sa to už nebude opakovat', pretože neexistujú žiadne d’alšie príklady, odkedy je svet svetom; príde deň, ked' to už ani nebudeme môct' vysvetlit"“ (Jankélévitch 2015, 183). Jankélévitch trvá na tom, že výnimočný charakter nacistickej genocídy nedovoluje porovnávat’ ju s inými vojnovými nešt’astiami $\mathrm{v}$ dejinách, ak len nechceme tábory smrti presunút' do dejinného a zl'ahčujúceho kontextu, a tak ich banalizovat'.

Téza o neporovnatel'nosti holokaustu ako zločinu proti l'udskosti s inými aktmi vojnového násilia $\mathrm{v}$ dejinách $-\mathrm{a} \mathrm{z}$ toho vyplývajúci imperatívny príkaz pre pamät však neboli napohl'ad evidentné. Bolo treba použit' aj inú ako právnu argumentáciu. Žiadalo sa uviest' špecifické charakteristiky zločinov nacistickej genocídy, ktoré ich odlišovali od iných vojnových zločinov. Totiž chápanie holokaustu ako výnimočnej dejinnej udalosti môže navodzovat' predstavu, akoby táto udalost' stála „mimo dejín“, ked’že v nich nemá nijaký svoj historický precedens, nijaký dejinný predobraz, na základe ktorého by ju bolo možné objasnit' a pochopit'. Tento prístup však vyvolal určité pochybnosti. Jankélévitchov intelektuálny generačný druh P. Ricoeur v rámci svojej typológie zneužívania pamäti v diele Pamät', dejiny, zabudnutie (o ktorej tu ešte bude reč) varoval práve pred takýmto typom uvažovania. $Z$ jeho rozborov vyplýva, že vyčleňovanie určitej dejinnej udalosti na okraj dejín alebo mimo nich smeruje k nastoleniu nerovnováhy medzi pamät'ou a históriou. Treba sa preto pristavit' pri Jankélévitchových filozofických a morálnych argumentoch, ktorými opodstatňuje tézu o výnimočnosti zločinu holokaustu a bráni myšlienku pamäti.

Klúčový Jankélévitchov argument sa odvíja od jeho tvrdenia o metafyzickom charaktere nacistických zločinov exterminácie, danom tým, že išlo o ,zločiny proti l'udskosti, to znamená proti l'udskej podstate, či skôr proti ,človečenskosti` človeka 
vôbec“ (Jankélévitch 1986, 22). Pôvodcovia týchto zločinov „,nechceli zničit” viery odsúdené ako mylné ani doktríny považované za zhubné: rasistická genocída sa v bolestivom tele miliónov mučeníkov pokúsila zničit' samo bytie človeka, Esse. Rasistické zločiny sú útokom na človeka ako človeka... rasista mieril priamo na ipseitu bytia, to znamená na l'udskost' každého človeka“ (Jankélévitch 1986, 22). Nejde tu len o číre masívne potláčanie l’udských práv, ktoré sa v dejinách udialo už neraz. Ciel’om je úplné vyhladenie, ,vymazanie židovského človeka z povrchu zemského“, a to výlučne „z nehmatatel'ných metafyzických dôvodov“ (Jankélévitch 2015, 221), ked’že tento človek sa neprevinil ničím iným, iba tým, že existuje. V intenciách Jankélévitcha ponižovanie a zabíjanie niekoho len z toho dôvodu, že existuje, znamená popretie základného princípu, z ktorého vychádzajú l'udské práva: ontologickej rovnosti všetkých l'udí, odvodenej z prirodzených práv. Prehliadnut' to podl’a neho znamená banalizovat', čiže hodit' všetky zločiny v dejinách do jedného vreca. Nepremlčatel’nost' zločinov holokaustu je pre neho „absolútnym kategorickým imperatívom“ (Schwab 2015, 176), pokial' sa len právne vymazanie zločinu nemá podpísat' pod nový zločin. „Tento proti-prirodzený zločin, tento nemotivovaný zločin, tento obludný zločin je doslova metafyzický... Ked' čin popiera podstatu človeka ako takého, tak premlčanie, ktoré by viedlo k odpusteniu v mene morálky, samo odporuje morálke. Nie je protirečivé a absurdné dovolávat' sa tu odpustenia? Zabudnút' na tento obrovský zločin proti l'udskosti by bol nový zločin proti l'udskému rodu“ (Jankélévitch 1986, 25). Možno tvrdit', že Jankélévitch svojou filozofickou optikou - v ktorej obnažil skutočnú povahu holokaustu ako „metafyzického zločinu“ - dovidel d’alej ako iní. Poukázal na to, že moderný človek je tu konfrontovaný $\mathrm{s}$ absolútnym zlom už nie v rovine zlých úmyslov, ale v rovine bytia, $v$ rovine existencie človeka ako takej. Povinnost' objasnit' udalost' holokaustu a nezabudnút' na ňu tak logicky vyplynula $\mathrm{z}$ jeho filozofického postoja. Holokaust v jeho očiach znamenal vážnu urážku človeka ako takého, nielen osobnej cti a dôstojnosti jednotlivcov.

Jankélévitch sa inšstruktívne vyrovnáva aj s argumentmi novodobých sofistov, odporúčajúcich zabudnút' na Auschwitz. Totiž obhajcovia premlčania zločinu holokaustu zvyčajne poukazujú na to, že uzákonenie nepremlčatel'nosti vyvoláva novú nenávist' a znemožňuje dobré fungovanie spoločnosti. Pritom využívajú filozofický sofizmus (založený na zdanlivom vedení a argumentačných úskokoch) v snahe dokázat', že premlčanie, a teda zabudnutie, je súčast' našej prirodzenosti. Jankélévitch ale nepripúšt'al, že by premlčanie bolo prirodzeným právom. V rozhovore z roku 1979, ked' vo Francúzsku došlo k novému rozmachu antisemitizmu a neonacizmu, je jeho reakcia na argument o prirodzenosti zabúdania jednoznačná a jasná: „Áno, ale prenasledovanie vojnových zločincov je morálna práca a nikto nepovedal, že morálna práca má potvrdit' prirodzenost'. Prirodzenost' je tiež krvilačná, zábudlivá, lahostajná, to 
znamená, všetko to, čo človek musí prekonat'. Človek je obdarený pamät’ou, pomocou ktorej môže bojovat' práve proti tejto l'ahostajnosti, proti tomuto zabúdaniu, ktoré nemá nič normatívne ani ideálne, ale ktoré predstavuje zotrvačnost' prirodzenosti, na ktorú človek reaguje svojimi myšlienkami, skutkami a svojou vernost'ou minulosti“ (Jankélévitch 2015, 221). Proti l'ahostajnosti a tendencii zabudnút' zdôraznil: „Zabudnutie nie je l'udské, l'udská je pamät', bdelost' a vernost““ (Jankélévitch 2015, 224).

Vynára sa otázka, akú silu má tento typ argumentácie, ktorá pamäti imperatívne ukladá povinnost'? Venujeme v tejto súvislosti pozornost' názorom Ricœura, odhal'ujúcim úskalia tejto radikálnej perspektívy.

\section{Pochybnosti o povinnosti pamäti: hl'adisko P. Ricœura}

Paul Ricœur ako jeden z prvých autorov vo Francúzsku spochybnil legitímnost' pamäti ako kategoricky vyžadovanej povinnosti. Svoje monumentálne dielo Pamät', dejiny, zabudnutie z roku 2000 uviedol vetou: „Mätie ma znepokojujúce divadlo, ukazujúce príliš vel'a pamäti tu, príliš vel’a zabudnutia inde, a nehovoriace nič o vplyve spomienok a zneužitia pamäti - a zabudnutia“ (Ricœur 2000, I). ${ }^{5}$ V súvislosti s otázkou povinnosti pamäti jeho zámerom bolo odhalit' riziká spojené s extrémnym tlakom na presadenie povinnosti pamäti a upriamit' pozornost' na to, čo nazval práca pamäti. Nie je preto náhodné, že otázku povinnosti pamäti artikuluje v rámci kapitoly venovanej praktickému využitiu pamäti, kde rozoberá formy jej zneužitia. Pravda, z toho by sa l'ahko dal vyvodit' záver, že v spore o povinnost' pamäti stojí na strane tých autorov, ktorí túto myšlienku jednoznačne zavrhujú (ako historici P. Nora alebo Tz. Todorov) alebo ktorí v súvislosti s protirečeniami súvisiacimi s povinnost'ou pamäti obhajujú právo na zabudnutie (H. Rousso). Ricœurove pochybnosti vtelené do vyjadrenia „príliš vel’a pamäti tu - príliš málo inde“ dokonca niektorí kritici pochopili ako „križiacku výpravu“ proti povinnosti pamäti. Osobitne sa pozastavili nad frázou o „údajnej povinnosti pamäti“ (Ricœur 2000, 105) v subkapitole o problematike povinnej pamäti. Treba sa preto venovat' Ricœurovým rozborom, v ktorých otázka povinnosti pamäti figuruje v kontexte so zneužitím pamäti, a zistit', či za jeho argumentmi treba hl'adat' odmietnutie povinnosti pamäti ako takej.

Aby sa vyhol nediferencovanému narábaniu s pojmom zneužitia pamäti, Ricœur zvolil tri úrovne reinterpretácie spomínaného zmätku medzi „privel’a“ a „primálo“ pamäti a v ich rámci rozlíšil tri formy zneužitia kolektívnej pamäti. Na úrovni patologickoterapeutickej je to blokovaná, potlačená pamät' (fr. la mémoire empêchée). Ricœur tu

\footnotetext{
${ }^{5}$ Možno oprávnene predpokladat', že Ricœur reagoval aj na Jankélévitchovu kategorickú požiadavku týkajúcu sa pamäti na holokaust, aj ked' ho v diele výslovne necitoval. Nemožno si totiž nevšimnút', že problematiku pamäti na titulnej strane Ricœurovho diela Pamät', dejiny, zabudnutie uvádza motto Jankélévitcha.
} 
využíva kategórie z psychoanalýzy, aby poukázal na to, že kolektívna pamät’ vykazuje podobné problémy ako traumatizovaná individuálna pamät. ${ }^{6} \mathrm{Na}$ praktickej úrovni ide o manipuláciu pamäti nositelmi moci (fr. la mémoire manipulée). Na tejto úrovni nie je v hre traumatizovaná pamät', ale pamät' inštrumentalizovaná. Táto úroveň je najlegitímnejšou platformou na zneužitie tak pamäti (ak jej je privel'a), ako aj zabudnutia (ak jej je nedostatok). Špecifikom tohto prístupu je prepojenie pamäti a identity, mobilizácia pamäti pri hladaní a znovunachádzaní identity, osobnej aj kolektívnej, a to aj ideologizáciou pamäti. Ricœur sa tu prekvapivo prihlasuje k Tz. Todorovovi a jeho prísnej kritike „súčasného ošial’u zo spomienkových osláv“ (Ricœur 2000, 104). A práve tu nachádza impulz pre úvahy o tretej forme zneužitia pamäti na eticko-politickej úrovnio povinnej, vynútenej pamäti (fr. la mémoire obligée) a v jej rámci o otázke povinnosti pamäti. ${ }^{7}$

Riešenie t’ažkostí s povinnost'ou pamäti, zodpovedanie otázky o mieste a význame povinnosti pamäti podl'a Ricœura vyžaduje konfrontovat' živú pamät' tých, čo prežili, s nestranným a kritickým pohl'adom historika. No práve $\mathrm{v}$ tomto bode sa mu povinnost' pamäti javí obzvlášt' plná nejednoznačností. Jeho obava pramení z toho, že príkaz adresovaný pamäti sa bude chápat' ako výzva pamäti, aby sa obišlo dielo histórie, teda že tu hrozí riziko postavenia pamäti proti histórii. Znepokojuje ho však aj opačný nárok, keby k nemu došlo, že by sa pamät redukovala na jednoduchý predmet histórie. Nejasnosti vyvoláva aj d’alšia zo série otázok, a tá sa týka gramatického paradoxu, ktorý zakladá výslovný príkaz pamätat' si. Ide napríklad o to, že od pamäti sa imperatívne do budúcnosti vyžaduje, aby bola strážkyňou minulosti, teda že pamät' má nútene plnit' nejakú úlohu, hoci spomínanie je pôvodne spontánny akt. To všetko vedie Ricœura $\mathrm{k}$ tvrdeniu, že „povinnost' pamäti predstavuje zároveň vrchol dobrého použitia aj vrchol zneužitia vo výkone pamäti“ (Ricœur 2000,106). Z tejto jeho formulácie by však bolo predčasné vyvodzovat' záver, že jeho postoj k tejto otázke je jednoznačne odmietavý; skôr ho možno označit' za zdržanlivý.

Práve preto, že Ricœur si uvedomoval možné zneužitie povinnosti pamäti pri jej imperatívnom vynucovaní, jeho principiálnou starostou je úsilie skíbit' ju s dvoma d'alšími schopnost'ami, s prácou pamäti a prácou smútku. Z jeho hl'adiska práca pamäti a práca smútku - na rozdiel od povinnosti pamäti - neobsahujú imperatívny element. Chýba im dvojitá charakteristika vlastná povinnosti, ktorá pri využití pamäti predstavuje problém: pôsobenie na túžbu zvonka a uplatnenie donútenia, subjektívne

\footnotetext{
${ }^{6}$ „Privel'a pamäti obzvlášt' pripomína nutkanie opakovat', o ktorom nám Freud hovorí, že vedie k nahradeniu skutočnej pamäti, ktorá by mohla zmierit' prítomnost' s minulostou, prechodom k činu“ (Ricœur 2000, 96), ktorému však chýba aktivita spomínania.

${ }^{7}$ Detailnejšie o zneužití pamäti pozri Ricœur $(2000,83$ - 111).
} 
pocit'ovaného ako povinnost' (napríklad v podobe povinnej pamäti oktrojovanej štátom). Najmenej sporný spôsob zjednotenia týchto dvoch čŕt povinnosti Ricœur vidí v myšlienke spravodlivosti, pri ktorej dôležitú rolu hrá morálka. Povinnost' pamäti potom znamená povinnost' učinit' zadost' spravodlivosti, a teda zaistit', aby sa pamät' na inštitucionálnej úrovni nevyužívala mravne neprístojným spôsobom, zneužívajúcim odkaz na minulost'. ${ }^{8}$ Spravodlivost', spravodlivá pamät' má garantovat' morálne využitie pamäti. To vyžaduje: starost' o druhých, teda reorientáciu povinnosti pamäti na iného než seba, d’alej záväzok splatenia dlhu, nielen materiálneho, ale aj morálneho $\mathrm{v}$ podobe úcty voči tým, ktorí tu už nie sú, a napokon uznanie morálnej priority obetiam (Ricœur 2000, 108).

Rozvinutím úvahy o povinnosti pamäti na pôde myšlienky spravodlivosti Ricœur načrtáva určité východisko z t’ažkostí, ktorým bolo vystavené použitie pamäti v spojení s imperatívne vnucovanou povinnost'ou. V tejto súvislosti je dôležité uviest', že aj ked' tu prioritný význam nadobúda pojem práca pamäti, v ktorom sa odráža spôsob, ako môže spoločnost' dospiet' k zmiereniu samej so sebou, povinnost' pamäti sa z myšlienky spravodlivosti nevytratila. Ricœurovou snahou však je docielit', aby kolektívna pamät' neostala uväznená $\mathrm{v}$ traume minulosti. „Práve spravodlivost', ktorá z traumatizujúcich spomienok získava príkladnú hodnotu, obráti pamät' na projekt; a práve ten istý projekt spravodlivosti dáva povinnosti pamäti formu budúcnosti a imperatívu. Možno teda tvrdit', že povinnost' pamäti ako imperatív spravodlivosti sa projektuje ako tretí termín v mieste spojenia práce smútku a práce pamäti“ (Ricœur 2000, 107). Z Ricœurových úvah jednoznačne vyplýva i to, že požiadavku povinnosti pamäti nemožno abstrahovat’ od historických podmienok, v ktorých sa objavila - v Západnej Európe, a osobitne vo Francúzsku, po udalosti holokaustu. V tomto kontexte môže vzniknút' otázka, do akej miery je prístup smerujúci k presadeniu myšlienky spravodlivej pamäti ako sily združujúcej prácu pamäti a prácu smútku uspokojivým riešením.

Hned' treba povedat', že s ohl'adom na pretrvávajúcu traumu z holokaustu v súčasných spoločnostiach niektorí komentátori neprijímajú s porozumením Ricœurovu interpretáciu o potlačení a návrate potlačeného, pokial' ide o amnéziu príznačnú pre traumatizované spoločnosti. Nie všetci si myslia, že pojem vypožičaný z psychoanalýzy je tu vhodný a plodný. Podl’a R. Robin-Maire ticho, mlčanie o holokauste zvyčajne nie je

\footnotetext{
${ }^{8}$ Paralelu a doplnok k zneužívaniu pamäti formou povinnej, riadenej pamäti na inštitucionálnej úrovni predstavuje zneužitie zabudnutia. Okrem patologického a manipulatívneho zabudnutia si Ricœur všíma zabudnutie formou politicky nariadenej povinnosti zabudnút - amnestie. Svoje protiargumenty ozrejmuje najmä v súvislosti s ostrou kritikou amnestie ako inštitucionálnej formy zabudnutia, hraničiacej s amnéziou, ked’ súdny akt štátu imituje odpustenie, hoci so skutočným odpustením nemá nič spoločné. „Blízkost’ medzi amnestiou a amnéziou, viac ako fonetická, ba aj sémantická, signalizuje existenciu tajného paktu s odopretím pamäti; tento pakt fakticky vzd’al'uje amnestiu od odpustenia po tom, ako navrhol jeho imitáciu“ (Ricœur 2000, 586).
} 
výrazom potlačenia pamäti, ale kolektívnou a individuálnou stratégiou s ciel'om zabudnút', íst' d'alej a správat' sa tak, akoby sa nič nestalo (Robin-Maire 2005, 272). J. A. Barash Ricœurovi vytýka, že jeho analýza zlyháva pri identifikovaní symbolickej sily, ktorá napája kolektívnu pamät', a že jeho metóda zatemňuje špecifikum skúseností vlastných politickým kolektívom, ked’že kolektívne spomienky vysvetluje analógiou s individuálnymi psychickými procesmi a s princípmi odvodenými z individuálnej morálky. Myslí si, že pokial' ide o genocídy dvadsiateho storočia - najmä o vyhladzovanie židovských komunít nacizmom -, kategórie dlhu, práce pamäti a práce smútku míňajú zmysel. Za realitou fyzického zmiznutia rozsiahlych komunít treba identifikovat' prerušenie kontinuity samého európskeho sveta. Podl’a jeho názoru to podstatné tu ,absolútne uniká kategóriám kvantifikácie z hl’adiska psychického zabúdania, ako aj kategóriám individuálnej morálky aplikovanej na kolektívne osoby, teda na označenie dvoch skupín, ktoré sa vzájomne konfrontujú v podobe dlžníkov alebo veritel’ov, pacientov a terapeutov. Nejde tu ani tak o vykonanie ,práce na nápravu prílišnej pamäti alebo prílišného zabudnutia, ako skôr o to, aby sme sa prebudili k pochopeniu, že toto zmiznutie zasahuje samu identitu Európy takej, ktorá má svoje korene v Antike, a ktorú genocídy dvadsiateho storočia, viac ako ktorákol'vek iná historická udalost', nenávratne znetvorili““ (Barash 2006, 195). Barash tak nepriamo nadväzuje na myšlienku, ktorú predoslal už Jankélévitch. Pripomeňme, že Jankélévitch zdôvodnil svoju kategorickú požiadavku zákazu zabudnutia argumentom o historickej jedinečnosti holokaustu ako doslova „metafyzického“ zločinu, teda zločinu, ktorý napadol l'udskost' človeka tým, že čast' l'udského rodu odsúdil do roly nežiaducich, ktorým je odopreté právo existovat'.

Iní komentátori, naopak, oceňujú Ricœurovo úsilie nájst' správnu mieru medzi povinnost'ou pamäti a formami jej zneužitia, najmä na eticko-politickej úrovni. Aj ked' niektoré jeho formulácie mohli vyvolat' rozpaky, ${ }^{9}$ súhlasíme s názorom J. Michela, že by bolo nedorozumením interpretovat' to ako Ricœurovu snahu o likvidáciu povinnosti pamäti. Michel oprávnene zdôrazňuje, že Ricœur neodsudzuje princíp povinnosti pamätat' si ako taký, ale jeho zneužívanie v rámci toho, čo označuje ako ,príliš vel’a pamäti“ a čoho patogénne účinky odhaluje na troch úrovniach. „Inými slovami, pamätový príkaz na obete masových zločinov má ústredné miesto v architektúre Pamäti, dejín, zabudnutia, najmä v časti venovanej holokaustu“ (Michel 2018, 109 - 110). Dôležitý - aj so zretel'om na Jankélévitchovu tézu o historickej jedinečnosti holokaustu - je aj vysvetlujúci komentár F. Dossa, Ricœurovho dvorného životopisca, detailne mapujúceho jeho intelektuálny a politický vývin. „Ricœur poukazuje na morálnu jedinečnost’ holokaustu ako pamäti bez proti-pamäti, čo z neho činí nešt’astie, ktoré je neporovnatel'né

\footnotetext{
${ }^{9}$ Rozpaky vznikajú napríklad vtedy, ked' Ricœur pripúšt’a svoju názorovú blízkost's tézami Tz. Todorova, známeho kritika povinnosti pamäti.
} 
s inými traumami. Naproti tomu potvrdzuje, po mnohých d'alších, ako Hannah Arendtová, porovnatel'nost' tohto obdobia ako historického okamihu vo vzt'ahu $\mathrm{k}$ iným totalitným režimom“ (Dosse 2008, 650 - 651). Podl’a Dossa to však neznamená, že by Ricœur tento traumatizujúci moment banalizoval. „Celé Ricœurovo myslenie je myslením nevyhnutnej okl'uky a ak povinnost' pamäti zostáva horizontom spočívajúcim na zaistení spravodlivosti pre obete, pripomína nevyhnutnú obchádzku prostredníctvom nevyhnutnej práce epistemológie dejín“ (Dosse 2008, 650). Ak uznáme, že spravodlivost' je u Ricœura zjednocujúcou kategóriou, ktorá vyžaduje prácu pravdy v troch previazaných formách - vôla po spravodlivosti voči druhým, myšlienka dlhu a morálna priorita poskytnutá obetiam, tak možno súhlasit's Dossom, podl'a ktorého kritika na adresu Ricœura, že sa vzdal povinnosti pamäti, nie je nijako podložená. Najmä nie preto, že bol filozofom dlhu, pričom splácanie dlhov chápal ako povinnost': „Povinnost’ pamäti je prejavit' spravodlivost' pamätaním na niekoho iného než na seba“"(Ricœur 2000, 108).

\section{Záver}

Môže si povinnost' pamäti zachovat' svoj zmysel napriek riziku jej zneužitia? Ricœur, ktorého reflexia o pamäti vznikla s odstupom viac ako pol storočia od konca druhej svetovej vojny, navrhol uvažovat' o povinnosti pamäti v kontexte s myšlienkou spravodlivosti, aby tak zmiernil jej imperatívny formát. Uznáva dôležitost' výkonu spravodlivosti vo vzt’ahu k minulosti, usiluje sa však nájst' správnu mieru medzi imperatívne nanútenou povinnost'ou pamäti a zabúdajúcou pamätou. Prioritne sa zasadzuje za prácu pamäti v spojení s prácou smútku, čím naznačuje, že neštastná pamät' sa môže zmenit' na zmierenú pamät'. Uvedomuje si, že udalosti ako holokaust a d’alšie závažné zločiny dvadsiateho storočia, ktoré hraničia s nepredstavitelným a predstavujú traumu pre individuálnu aj kolektívnu pamät', si vyžadujú, aby sa o nich hovorilo. Terapiu kolektívnej pamäti premlčaním genocídy odmieta. Ide mu však o to, aby spôsob vypovedania o zle bol „pokojný, bez hnevu“ (Ricœur 2000, 589). Spravodlivost' v jeho očiach znamená aj požiadavku nepomstit' sa.

Naproti tomu Jankélévitchov prístup je nekompromisný - holokaust ako zločin proti l'udskosti je útokom na princíp l’udskosti, ktorý zjednocuje celý l'udský rod. K pamäti na holokaust nás zaviazali obete, ktoré zostali v táboroch smrti. Nejde o našu volbu, ale o povinnost', v mene zachovania samých základov morálky. Kategorický zákaz zabudnutia Jankélévitch vzt’ahuje na zločin holokaustu, no jeho filozofický rozbor povahy zločinov nacistickej genocídy možno dnes uplatnit' na celú skupinu zločinov vyhladzovania a zotročovania, či už sa týkajú vzdialenejšej, alebo celkom nedávnej minulosti (arménska genocída, apartheid...). Niekto ešte aj dnes možno žije v mylnom presvedčení, že holokaust, tento archetyp zločinu proti l'udskosti, môže byt' predmetom 
polemiky alebo záležitost’ou vyjadrenia slobodného názoru. Jankélévitchova argumentácia dostatočne presvedčivo ukazuje, že právo na slobodu prejavu tu naráža na nezlučitel'nost' so základnými hodnotami európskej civilizácie. V prvom rade na hodnotu rešpektu k právu nášho blížneho na existenciu: ,náš blížny nám nie je povinný ničím na oplátku... iba ak rovnakým rešpektom“ (Jankélévitch 1986, 23). Otázku povinnosti pamäti možno v tomto svetle chápat' aj ako otázku boja za ochranu základných l'udských práv a hodnôt európskej civilizácie.

Otvorenou zostáva otázka, kto má byt' subjektom povinnosti pamäti, komu sa táto povinnost' ukladá. Z Jankélévitchových úvah vyplýva, že ide o morálnu povinnost', ktorá sa týka všetkých l'udí, pretože v zločine proti l'udskosti bolo urazené celé l'udstvo. Proti tejto perspektíve, ktorá spája povinnost' pamäti s univerzálne platným morálnym imperatívom, stojí hl'adisko, ktoré túto povinnost' legitimizuje politicky. Napríklad podla M. Bienenstockovej povinnost' pamäti je „povinnost' výsostne politická“ (Bienenstock 2014, 36), a nie morálna, a preto táto autorka navrhuje uprednostnit' skôr optiku Hegla ako Kanta (odhliadnuc od toho, že títo nehovorili o povinnosti pamäti). Z tohto hl'adiska štát a jeho inštitúcie s ich pamät'ovými zákonmi majú reprezentovat' určitú etickú podstatu, ktorá zahŕňa pamät' na zločiny, už aj preto, že naše štáty, a v istom zmysle naše spoločnosti sa na týchto zločinoch historicky podiel'ali. Mnohí môžu tieto usmernenia súvisiace $\mathrm{s}$ rolou štátu $\mathrm{v}$ otázke povinnosti pamäti považovat' za užitočné. No treba vziat' do úvahy riziko, že povinnost’ pamäti ako politický imperatív sa stane predmetom účelového kalkulovania, pokial' ju nevyváži morálny záväzok verejnosti, nezávislý od oficiálneho príkazu. V tejto súvislosti neprekvapuje tvrdenie N. Maslowského, podl'a ktorého nie všetkých zjednocuje spoločný ciel', spočívajúci v kontrole pamäti štátom. „Argumentácia zdôrazňujúca morálku hrá významnejšiu úlohu ako mocenské vzt’ahy“" (Maslowski 2014, 80).

\section{Literatúra}

BARASH, J. A. (2006): Qu'est-ce que la mémoire collective? Réflexions sur l'interprétation de la mémoire chez Paul Ricœur. Revue de métaphysique et de morale, 2 (50), 185 - 195. DOI: https://doi.org/10.3917/rmm.062.0185

BIENENCTOCK, M. (2014): La mémoire: un „devoir“? Réflexions sur les sens religieux, moral ou politique prêtés à la notion de „,devoir“, dans l'expression commune ,devoir de mémoire“. In: Devoir de mémoire? Les lois mémorielles et l'Histoire. Sous la direction de Myriam Bienenstock. Paris: Éditions de l'Éclat, 15 - 37.

BROHM, J.-M. (2015): Postface. In: Vladimir Jankélévitch. L'esprit de résistance. Textes inédits, 1943 - 1983. (Textes réunis et présentés par Françoise Schwab, avec les contributions de JeanMarie Brohm et Jean-François Rey). Paris: Albin Michel.

DOSSE, F. (2008): Paul Ricour. Les sens d'une vie (1913 - 2005). Paris: La Découverte.

JANKÉLÉVITCH, V. (1986): Imprescriptible. Pardonner? Dans l'honeur et la dignité. Paris: Éditions du Seuil. 
JANKÉLÉVITCH, V. (2015): L'esprit de résistance. Textes inédits, 1943 - 1983. (Textes réunis et présentés par Françoise Schwab, avec les contributions de Jean-Marie Brohm et Jean-François Rey). Paris: Albin Michel.

KATTAN, E. (2002): Penser le devoir de mémoire. Paris: PUF.

LALIEU, O. (2001): L' invention du „devoir de mémoire“. Vingtième siècle. Revue d'histoire, 1 (69), 83 - 94. DOI: https://doi.org/10.3917/ving.069.0083

LEVI, P. (1995): Le devoir de mémoire. Entretien avec Anna Bravo et Frederico Cereja, traduit de l'italien par Joël Gayraud, avec une introduction et une postface de Frederico Cereja. Paris: Éd. Mille et une nuits.

MASLOWSKI, N. (2014): Politika paměti jako nástroj manipulace a morálky. In: Maslowski, N., Šubrt, J. a kol.: Kolektivní pamět'. K teoretickým otázkám. Praha: Karolinum, $69-81$.

MICHEL, J. (2018): Le devoir de mémoire. Paris: Humensis.

RICEUUR, P. (2000): L'histoire, mémoire, pardon. Paris: Éditons du Seuil.

ROBIN-MAIRE, R. (2005): Le devenir victimaire de l'Allemagne. In: Le dévoir de mémoire et les politiques du pardon. Sous la dir. M. Labelle, R. Antonius, G. Leroux. Québec: Presses de l'Université du Québec, 269 - 285.

SCHWAB, F. (2015): Introduction. L'imprescriptible. In: Jankélévitch, V. (2015): L'esprit de résistance. Textes inédits, 1943 - 1983. (Textes réunis et présentés par Françoise Schwab, avec les contributions de Jean-Marie Brohm et Jean-François Rey). Paris: Albin Michel.

SIVÁK, J. (2013): Paul Ricœur ako metodológ dejín. Vo svetle diela Čas a rozprávanie. Filozofia, $68(9), 752-765$

SUCHAREK, P. (2017): Zmierenie nie je odpustenie. Chvála odpustenia. Filozofia, 72 (6), 417 - 428.

Táto práca vznikla v rámci projektu VEGA 2/0049/20 K idei l’udských práv-koncepty, problémy, perspektívy.

Dagmar Smreková

Filozofický ústav SAV

Klemensova 1

81364 Bratislava

Slovenská republika

e-mail: dagmars1@ seznam.cz

ORCID: https://orcid.org/0000-0001-6946-0134 